\title{
Defensins in Ulcerative Colitis
}

\author{
Zhanju Liu ${ }^{1}$ and Yurong Yang 2 \\ ${ }^{1}$ Department of Gastroenterology, The Shanghai Tenth People's Hospital, \\ Tongji University, Shanghai, \\ ${ }^{2}$ College of Animal and Veterinary Engineering, \\ Henan Agricultural University, Zhengzhou \\ China
}

\section{Introduction}

Defensins and cathelicidins are the two major endogenous antimicrobial peptide families in mammals, which are abundant components of phagocytic leukocytes and are released by epithelial cells at mucosal surfaces. Defensins are antimicrobial peptides produced at a variety of epithelial surfaces. In the small intestine Paneth cells secrete a-defensins and additional antimicrobial peptides at high levels in response to cholinergic stimulation and when exposed to bacterial antigens. In the intestinal tract $\alpha$ - and $\beta$-defensins contribute to host immunity and assist in maintaining the balance between protection from pathogens and tolerance to normal flora. However, attenuated expression of these defensins compromises host immunity and hence may alter the balance toward inflammation. Altered defensins production is suggested to be an integral element in the pathogenesis of ulcerative colitis (UC). Recent years, the defensins have attracted great attention because of their roles in the organism defense system. This review highlights the current knowledge of defensins, distribution, structures, the diverse functions in the immune response and the changes of defensins expression in UC and the potential role in the pathogenesis of UC.

\section{Structures of defensins}

Antimicrobial peptides are gene-encoded natural antibiotics produced by virtually every life form studied (Boman, 1995; Zasloff, 2002). In mammals, defensins are a major (if not predominant) group of antimicrobial peptides. In the 1980s, Lehrer et al. first found a series of small molecules cationic peptides with similar structures to rabbit and human neutrophil cytoplasmic granules, which were first named "defensins" (Lehrer et al., 1980). A fundamental characteristic of defensins peptides is the presence of three intramolecular disulfide bonds (Ganz, 2003). The defensins are thus subdivided into three subgroups (designated $\alpha-, \beta-$, and $\theta$-defensins). The subgroups are based largely on the connectivity of three cystine linkages (Table 1), but structural features of the gene and precursor are also further distinguishing characteristics.

The three-dimensional structures of several $\alpha$ - and $\beta$-defensins have been determined by both nuclear magnetic resonance (NMR) and X-ray crystallography techniques (Hill et al., 1991; Zhang et al., 1992; Pardi et al., 1992; Skalicky et al., 1994; Zimmermann et al., 1995; 
Sawai et al., 2001). Although crystal structures of some defensins are made up of dimers or multimers, it has not been yet clear whether these multimers are the biologically relevant to different forms of defensins.

\begin{tabular}{|l|l|l|l|l|l|l|}
\hline Defensins & Peptide size & $\begin{array}{l}\text { Cysteine } \\
\text { Linkages }\end{array}$ & \multicolumn{1}{|c|}{ Size } & \multicolumn{1}{|c|}{$\begin{array}{l}\text { Expression } \\
\text { Sites }\end{array}$} & $\begin{array}{l}\text { Expression } \\
\text { Patterns }\end{array}$ & $\begin{array}{l}\text { Species } \\
\text { Distribution }\end{array}$ \\
\hline a-defensins & $30 \sim 34$ aa & $\begin{array}{l}1-6,2-4,3- \\
5\end{array}$ & $\begin{array}{l}90-105 \\
\text { aa }\end{array}$ & $\begin{array}{l}\text { Neutrophils, } \\
\text { Macrophage, } \\
\text { Paneth cells, } \\
\text { Reproductive } \\
\text { epithelia }\end{array}$ & $\begin{array}{l}\text { Mostly } \\
\text { constitutive }\end{array}$ & $\begin{array}{l}\text { Primates } \\
\text { Rodents } \\
\text { Rabbits }\end{array}$ \\
\hline$\beta$-defensins & $36 \sim 44$ aa & $\begin{array}{l}1-5,2-4,3- \\
6\end{array}$ & $\begin{array}{l}60-70 \\
\text { aa }\end{array}$ & $\begin{array}{l}\text { Mucosal } \\
\text { epithelia and } \\
\text { Skin, } \\
\text { Ruminant, } \\
\text { Heterophils, } \\
\text { Epididymis }\end{array}$ & $\begin{array}{l}\text { Mostly } \\
\text { inducible }\end{array}$ & $\begin{array}{l}\text { Primates } \\
\text { Rodents } \\
\text { Ruminants } \\
\text { Birds } \\
\text { Crustaceans }\end{array}$ \\
\hline $\begin{array}{l}\text {-defensins } \\
\text { 18 aa (two } \\
\text { connected } \\
\text { hemi-peptides } \\
\text { of 9 aa each) }\end{array}$ & $\begin{array}{l}1-1^{\prime}, 2-3, \\
2^{\prime}-3^{\prime}\end{array}$ & 90 aa & Neutrophils & Constitutive & $\begin{array}{l}\text { Non-human } \\
\text { primates }\end{array}$ \\
\hline
\end{tabular}

Table 1. Comparison of $\alpha$-defensins, $\beta$-defensins and $\theta$-defensins

The 3D structures of $\alpha$ - and $\beta$-defensins contain a canonical triple-stranded antiparallel $\beta$ sheet motif. Solution and crystallographic analyses of $\beta$-defensins have revealed that the aand $\beta$-defensins folds are similar as the amphipathicity is produced by the distribution of polar and hydrophobic side chains on the peptide surfaces. However, both $\beta$-defensins possess short $\alpha$-helical segments that $\alpha$-defensins lack. There is no evident relationship between $\beta$-sheet content and antimicrobial activity, and knowledge of the general structural factors that modulate the antimicrobial spectrum and activity of defensins is for the most part lacking.

The solution structures of closed circular rhesus $\theta$-defensin-1 (RTD-1) and its open chain analog (oRTD-1) have been determined by two-dimensional NMR. RTD-1 and oRTD-1 adopt very similar structures in water, containing an extended $\beta$-hairpin, structure with turns at one end in oRTD- 1 or in both ends in circular RTD-1. The double stranded $\beta$-sheet region of the two molecules is flexible, and, because the structures and flexibilities of RTD-1 and oRTD-1 are similar, the reduced antimicrobial activity of oRTD-1 relative to circular RTD-1 is attributable to the charged N- and C-termini of the oRTD-1 molecule (Trabi et al., 2001; Ouellette, 2006). In contrast to many antimicrobial peptides, RTD-1 has no amphiphilic character, even though surface models of RTD-1 exhibit a certain clustering of positive charges.

\section{Characteristics of defensins distribution}

Defensins are abundant in cells and tissues that are involved in host defense against microbial infections. Notably, the specific tissue distribution of defensins diverged rapidly during vertebrate evolution (Table 2). To date, 12 different human a-defensins and 48 
human $\beta$-defensins, 22 mouse $\alpha$-defensins and 26 mouse $\beta$-defensins have been identified and isolated (http://defensins.bii.a-star.edu.sg). In the alimentary tract of mammals, adefensins are highly expressed and largely confined to the small intestine, whereas $\beta$ defensins are found to be inducible expression at sites of infection or inflammation.

\begin{tabular}{|l|l|l|l|}
\hline Species & Neutrophil defensins & Paneth cell defensins & Epithelial cell defensins \\
\hline Human & $\mathrm{a}$ & $\mathrm{a}$ & $\mathrm{\alpha}$ and $\beta$ \\
\hline $\begin{array}{l}\text { Rhesus } \\
\text { monkey }\end{array}$ & $\mathrm{a}$ and $\theta$ & Not determined & $\beta$ \\
\hline Mouse & none & $\mathrm{a}$ & $\mathrm{a}$ and $\beta$ \\
\hline Rat & $\mathrm{a}$ & $\mathrm{a}$ & $\beta$ \\
\hline Pig & $\begin{array}{l}\text { Not detected in granule } \\
\text { extracts }\end{array}$ & Not determined & $\beta$ \\
\hline Cow & $\beta$ & none & $\beta$ \\
\hline Chicken & $\beta$ & Not determined & $\beta$ \\
\hline
\end{tabular}

Table 2. Diverse patterns of defensins expression in vertebrates

In human, a-defensins are expressed primarily in neutrophils, NK cells, certain $\mathrm{T}$ cell subsets, and in Paneth cells of the small intestine, where they may regulate and maintain microbial balance in the intestinal lumen. Moreover, low levels of a-defensins expression have been observed in epithelial cells of digestive tract, urogenital tract of mammalian and the kidney of rabbit. Human a-defensin-1, -2, -3, and -4, also known as neutrophil polypeptide (HNP), are located primarily in neutrophils, while human a-defensin- 5 and -6 (HD-5, HD-6) are secreted by the small intestinal Paneth cells. Mature a-defensins consist of 29-36 amino acids including six conserved cysteine residues.

$\beta$-defensins are the most widely distributed, being secreted by leukocytes and epithelial cells of many kinds. For example, they can be found on the tongue, skin, cornea, salivary glands, kidneys, esophagus, and respiratory tract. It has been suggested that some of the pathology of cystic fibrosis arises from the inhibition of $\beta$-defensins activity on the epithelial surfaces of the lungs and trachea due to higher salt content. $\beta$-defensins were first found from tracheal epithelium cells of cattle and in granulocytes of cattle (Diamond et al., 1991). The first human $\beta$-defensin (HBD-1) was discovered in 1995, which is mainly expressed in kidney, urogenital tract and other epithelial cells (Bensch et al., 1995). In 1997 Harder et al. first isolated and purified HBD-2 from the skin of psoriasis patients (Harder et al., 1997), and it is mainly expressed in damaged skin, oral mucosa and epithelium of infected lungs. HBD-3 is observed to be mainly expressed in human keratinocytes and airway epithelial cells. HBD-4 is mainly expressed in testis, uterus, neutrophils, thyroid, lung and kidney. In addition, HBD-5 and HBD-6 are only present in testicular cells (Harder et al., 2001; Garcia et al., 2001). $\beta$-defensins are composed of 36-42 amino acid residues, containing 6 conserved cysteine residues.

$\theta$-defensins are rare and thus far have been found only in the leukocytes of the rhesus macaque (Tran et al., 2008), and the olive baboon, Papio anubis, being vestigial in humans and other primates (Angie \& Michael 2008; Garcia et al., 2008). Interestingly, $\theta$-defensins are negative in humans and New World monkeys (Garcia et al., 2008; Nguyen et al., 2003). $\theta$ defensins are macrocyclic octadecapeptides expressed only in old world monkeys and orangutans, and produced by the pair-wise, head-to-tail splicing of nonapeptides derived from their respective precursors. Rhesus $\theta$-defensin-1 (RTD-1) is a unique cyclic antimicrobial peptide first identified in rhesus macaque leukocytes (Tang et al., 1999), and 
produced by a novel post-translational processing pathway involving the excision of two 9amino-acid oligopeptides from a pair of propeptides that is further stabilized by three disulfide bonds. $\theta$-defensins possess broad antimicrobial properties in vitro against bacteria, fungi, and viruses (Owen et al., 2004; Tran et al., 2008; Wang et al., 2004). Nevertheless, they exhibit very low levels of toxicity in vitro (Tran et al., 2008) and in vivo, indicating that they may have utilities as therapeutic agents.

\section{Biosynthesis of defensins}

\subsection{Regulation of $\alpha$-defensins biosynthesis}

a-defensins genes map to 8p21-8pter through 8p23 in human and are syntenic in mice (Ouellette, 2006; Ouellette et al., 1989b; Patil et al., 2004; Sparkes et al., 1989), which are expressed predominantly in myeloid cells or in Paneth cells (Selsted \& Ouellette, 1995).

\subsubsection{Transcriptional regulation}

Myeloid a-defensins mRNA are expressed almost exclusively in the bone marrow, where they are found at the highest levels in promyelocytes and at lower levels in myeloblasts and myelocytes (Yount et al., 1995). Enteric a-defensins occur exclusively in Paneth cells in normal small bowel (Cunliffe et al., 2001; Ouellette et al., 1999; Ouellette et al., 2000; Porter et al., 1997b; Selsted et al., 1992 ). Myeloid and Paneth cell a-defensins genes differ in that genes expressed in cells of myeloid origin consist of three exons, whereas those expressed in Paneth cells have only two exons (Bevins et al., 1996; Huttner et al., 1994; Jones \& Bevins, 1992; Jones \& Bevins, 1993; Lala et al., 2003). In Paneth cell a-defensins genes, the 5'untranslated region and the preprosegment are coded by exon 1, but an additional intron interrupts the $5^{\prime}$-untranslated region of myeloid a-defensins gene transcripts (Ouellette \& Selsted, 1996).

The differentiation of Paneth cells is determined by continuous Wnt signaling via the frizzled-5 receptor, and transcription of a-defensins genes in Paneth cell is mediated by $\beta$ catenin/TCF-4 recognition sites in the $5^{\prime}$-upstream regions of the gene transcription start sites as well as upstream of the gene coding for matrix metalloproteinase-7 (MMP-7), the mouse a-defensins convertase (Andreu et al., 2005; He et al., 2004; Pinto \& Clevers, 2005; Van et al., 2005). Monocytes and NK cells also contain a-defensins mRNAs and peptides, but regulatory elements equivalent to $\beta$-catenin/TCF-4 sites in Paneth cell $\alpha$-defensins genes remain to be found in myeloid a-defensins gene promoters.

\subsubsection{Posttranslational activation of $\alpha$-defensins}

Both $\alpha$ - and $\beta$-defensins are initially synthesized as preprodefensins, consisting of a characteristic amino terminal signal sequence, a propiece, and the mature peptide at the carboxy terminal end of the prepropeptide. The processing and release of a-defensins seem to be peptide- and host species-specific. $\alpha$-defensins have been isolated from primate leukocytes and neutrophils of several rodents including rats, rabbits, guinea pigs, and hamsters. Myeloid a-defensins RNAs are expressed almost exclusively in the bone marrow, where they occur at the highest levels in promyelocytes and at lower levels in myeloblasts and myelocytes. Although neutrophils contain high levels of a-defensins peptides, defensins mRNAs are degraded during neutrophil differentiation. In contrast, circulating monocytes contain both a-defensins mRNAs and peptides. The proteolytic pathway required to produce mature HNPs from their proforms is active only in myeloid cells (Valore \& Ganz, 
1992). Newly synthesized proHNPs are processed to mature defensins and then the mature peptides are stored in cytoplasmic granules. The propiece of proHNPs is important for the normal cellular trafficking during defensins biosynthesis and functions as an intramolecular inhibitor of defensins cytotoxicity (Liu \& Ganz, et al., 1995; Valore et al., 1996).

Unlike human neutrophil defensins, Paneth cell defensins HD-5 and HD-6 are stored as precursor in the secretory granules of Paneth cells (Ghosh et al., 2002). The biosynthesis of Paneth cell pro-a-defensins involves post-translational proteolytic activation. Although the enzymes that mediate pro- $\alpha$-defensins processing in myeloid and epithelial cells are likely to differ, the overall processing schemes are similar in that all are processed from precursor by specific proteolytic cleavage steps.

Evidences have been shown that a-defensins are present in murine Paneth cells under germfree conditions (Salzman et al., 2007; Ouellette \& Lualdi, 1990; Putsep et al., 2000), and in human Paneth cells prenatally (Mallow et al., 1996). These findings indicate that a-defensins expression is independent on bacterial stimulation. In contrast, expression of Reg3y and angiogenin in Paneth cells is closely associated with the presence of microbes in the intestinal lumen.

Transcription levels of a-defensins in Paneth cells are directed, in part, through factors intimately linked to cellular differentiation (Batlle et al., 2002). Clevers and colleagues have shown that Tcf7-L2 (also known as Tcf-4) is a key transcription factor for a-defensins expression in Paneth cells. Activity of this transcription factor is linked to Wnt/ $\beta$-Catenin signaling gradients in the crypt and appears to represent a master regulator for Paneth cell differentiation (Van et al., 2005). Defensins expression is found to be low in human neonates (Mallow et al., 1996), unweaned mice (Ouellette \& Cordell, 1988; Ouellette et al., 1989a) and rats, but increases dramatically with maturation. Aside from this developmental pattern, adefensin expression is relatively constitutive under most conditions. However, levels vary significantly in association with some disease states (Kelly et al., 2004; Wehkamp et al., 2004, 2005).

Additional regulatory mechanisms of a-defensins activity are granule secretion and proteolytic processing of precursor peptides (Bevins, 2004). Paneth cells secrete their dense secretory granules into the crypt lumen in response to bacterial products (including muramyl dipeptide, a component of bacterial peptidoglycan), but not to fungal or protozoal stimuli (Qu et al., 1996; Ayabe et al., 2000). These findings suggest that in vivo control of adefensins secretion in Paneth cells may be linked to microbial sensors. Interestingly, recent studies have identified that Paneth cells could express nucleotide oligomerization domain (NOD)2 (a critical intracellular pattern recognition receptor for muramyl dipeptide), whose precise functions in Paneth cells are yet to be clearly determined (Lala et al., 2003; Rumio et al., 2004; Kobayashi et al., 2005). Cholinergic agonists can also stimulate a-defensins secretion by a mechanism that appears to involve both increased cytosolic $\mathrm{Ca}^{2+}$ and mIKCa1 potassium channels (Satoh et al., 1995; Ayabe et al., 2002).

Proteolytic processing is an important step in regulating expression of active Paneth cellderived defensins. Paneth cell-derived a-defensins, like myeloid-derived a-defensins, are initially expressed as amino acid prepropeptides. After removal of the N-terminal signal sequence, the Paneth cell-derived a-defensins propeptides require processing by an endopeptidase to produce a mature active peptide. However, there are differences in this general theme when comparing with rodents and primates. MMP-7 (also known as matrilysin), an endoprotease expressed in mouse Paneth cells, is essential for processing of the a-defensins propeptide to active mature peptides in mice (Wilson et al., 1999; Ouellette, 
2005; Selsted \& Ouellette, 2005). MMP-7 processes the a-defensins propeptides to their active mature peptide counterparts at precisely the same cleavage site in vitro as identified in vivo (Selsted et al., 1992; Shirafuji et al., 2003). Polymorphic isoforms of a-defensins containing mutations at MMP-7 cleavage site exist in some mouse strains, which influence post-translational processing and yield differences in mature peptides. Characterization of Paneth cell-derived a-defensins suggests that MMP-7 is also the endoprotease responsible for processing in rats (Qu et al., 1996). In rhesus macaques, characterization of Paneth cellderived a-defensins indicates that trypsin is likely the endoprotease responsible for processing in these primates as well (Tanabe et al., 2004a, 2004b). In contrast, MMP-7 is not detected in human Paneth cells, and trypsin is the endoprotease expressed in Paneth cells, which is responsible for processing of a-defensins propeptides (Ghosh et al., 2002).

In humans Paneth cell-derived a-defensins are stored in secretory granules as propeptides (Ghosh et al., 2002; Cunliffe, et al., 2001). The propeptide trypsinogen is also stored in these same Paneth cell granules. Current hypotheses point that trypsinogen is activated to trypsin after secretion, which then converts proHD5 into mature HD5 in either the crypt or intestinal lumen. In contrast, some of the a-defensins pool in mouse Paneth cells is processed intracellularly and stored as mature MMP-7-cleaved peptides (Ouellette, 2005; Selsted \& Ouellette, 2005). Since proteolytic processing is central to the biology of Paneth cell a-defensins, it will be interesting to determine how and why rodents and primates diverged in their mechanisms for achieving this important post-translational modification.

Evidence for the key role of Paneth cell a-defensins in host defense against orally ingested pathogens comes from murine models. Targeted disruption of the MMP-7 gene, which encodes the processing endoprotease of murine Paneth cell a-defensins precursors, has shown to impair the ability of mice to produce active cryptdin. Compared to their wild-type littermates, the MMP-7 null mice cannot effectively clear orally administered noninvasive Escherichia coli, and they succumb more rapidly to lower doses of virulent Salmonella enterica serovar Typhimurium. However, MMP-7 may have other biological functions that could have altered the susceptibility to these bacterial challenges. Therefore, Salzman et al. utilized a complementary approach to analyze Paneth cell a-defensins function (Salzman et al., 2003). Mice were genetically engineered to express the human Paneth cell a-defensins HD5. Under transcriptional control of HD5's own endogenous promoter, these transgenic mice expressed HD5 in Paneth cells. Expression levels of the transgene were similar to those of the endogenous a-defensins (cryptdins), pointing that this murine model can assess the biological effects of physiologically relevant levels of HD5. The transgenic mice were more resistant to orally administered Salmonella. Thus, these two models point to a central role for Paneth cell a-defensins in innate immunity of the small intestine against orally ingested pathogens.

\subsection{Regulation of $\beta$-defensins biosynthesis}

It is likely that $\beta$-defensins gene products are produced and stored as mature peptides because pro- $\beta$-defensins have not been recovered from natural producing cells and insect cells, in which transfected with $\beta$-defensins cDNA always release bioactive mature $\beta$ defensins (Aono et al., 2006; Shi, 2007). HBD-1 is constitutively expressed in the epithelial cells in the small intestine and colon and its expression is not influenced by inflammation or bacterial infection. Despite normally absent, HBD-2 and HBD-3 can be induced in normal colon epithelial cells (O'Neil et al., 1999; Fahlgren et al., 2004). Induction of HBD-2 is an NF- 
$\mathrm{\kappa B}-$ dependent process in the intestinal epithelium because blocking NF- $\mathrm{\kappa B}$ activation could inhibit the upregulation of HBD-2 in response to IL-1 stimulation or bacterial infection (O'Neil et al., 1999; Voss et al., 2006). Unlike professional phagocytes and Paneth cells, epithelial cells expressing $\beta$-defensins do not have visible granules. How $\beta$-defensins are stored and released from intestinal epithelial cells remains obscure.

\subsection{Regulation of $\theta$-defensins biosynthesis}

Rhesus $\theta$-defensins peptides assemble from two distinct precursor molecules with each hemi-precursor contributing a nine-amino acid moiety to the final RTD-1 peptide, although the molecular mechanisms that catalyze or facilitate $\theta$-defensins assembly in primates are not understood (Tang et al., 1999). Rhesus pro-RTDs are products of different genes that resemble the three-exon myeloid a-defensins genes, except that they are truncated by stop codons in exon 3. In addition to heterodimeric RTD-1, homodimeric $\theta$-defensins RTD-2 and 3 have also been isolated from monkey neutrophils (Tran et al., 2002; Leonova et al., 2001). a-defensins gene mutations that give rise to the $\theta$-defensins genes (DEFT) apparently arise in Old World monkeys, because rhesus DEFT homologs have not been found in prosimians or in New World monkeys (Lehrer, 2004). Humans, chimpanzees, and gorillas lack $\theta$ defensins, because the DEFT genes of those species harbor mutations that create premature stop codons in the prepro regions of the precursors. However, at least one mutant human DEFT gene still is actively transcribed, and its nonfunctional mRNA accumulates to high abundance at several sites of expression (Cole et al., 2002).

\section{Role of defensins in immune response}

In the gastrointestinal tract, these peptides have bactericidal activity by forming micropores in the phospholipid bilayer of bacterial membranes, causing loss of structural integrity and collapse of the bacterial cells. This antimicrobial quality allows defensins to protect the host epithelium and stem cells from virulent pathogens and also help to regulate the number and composition of commensal microbiota (Ramasundara et al., 2009).

\subsection{Defensins in innate immunity}

The innate immunity is the most primitive defense system against pathogens, which has not only the generalized mechanical barriers and antibacterial action, but also includes functional defense barrier built by phagocytosis and inflammatory response.

\subsubsection{Antibacterial activity}

Defensins have a broad antibacterial spectrum, which can effectively kill Gram-negative and -positive bacteria, fungi, spirochetes, and some parasites. Importantly, a-defensins have stronger activity against Gram-positive bacteria, while the $\beta$-defensins have stronger activity against Gram-negative and -positive bacteria. HBD-3 has stronger bactericidal activity against Staphylococcus aureus, Streptococcus pyogenes, Pseudomonas aeruginosa, Escherichia coli and Actinomycetes in vitro (Maisetta et al., 2005).

The a- and $\beta$-defensins expressed in the alimentary tract of human and mice have activity profiles and expression patterns that overlap with other mammalian peptides (Table 3). Intestinal a-defensins have microbicidal activities against many Gram-positive ( $L$. monocytogenes, S. aureus) and Gram-negative bacteria (E. coli, S. typhimurium). Similarly, HD5 
is active against many bacterial species and the fungus C. albicans (Porter et al., 1997a; Ghosh et al., 2002; Ericksen et al., 2005). Surprisingly, initial reports indicate that HD6 has very poor antibacterial activity in vitro, despite similar ionic charge properties as HD5 (Ericksen et al., 2005). The most abundant $\beta$-defensins, expressed chiefly in the stomach and colon, also have bactericidal activity in vitro. HBD-2 is microbicidal against P. aeruginosa, E. coli and C. albicans, but less activity against Gram-positive S. aureus (Harder et al., 1997). In contrast, the more cationic HBD-3 has activity against S. aureus (Harder et al., 2001) and is less sensitive to the ionic composition of the assay medium. HBD-1 has antibacterial activity (Valore et al., 1998), but it is not potent in vitro like HD6.

\begin{tabular}{|l|l|l|l|}
\hline Defensins & Mr (kDa) & Tissue distribution & Stimuli \\
\hline HNP 1-4 & $3.5-4.5$ & $\begin{array}{l}\text { Sparse lamina propria } \\
\text { neutrophils in active } \\
\text { inflammation seen in scattered } \\
\text { intestinal epithelial cells }\end{array}$ & $\begin{array}{l}\text { Increased in active } \\
\text { inflammation but possibly } \\
\text { a result of increased } \\
\text { neutrophilic influx }\end{array}$ \\
\hline HD-5, HD-6 & $3.5-4.5$ & $\begin{array}{l}\text { Paneth cells and some villous } \\
\text { epithelial cells in normal } \\
\text { duodenum, jejunum and ileum } \\
\text { Paneth cell metaplasia }\end{array}$ & $\begin{array}{l}\text { Constitutively expressed, } \\
\text { however processing is } \\
\text { required for biological } \\
\text { activity }\end{array}$ \\
\hline HBD-1 & $3.5-4.5$ & $\begin{array}{l}\text { Colonic epithelia (and some } \\
\text { other mucosal epithelia) }\end{array}$ & Constitutively expressed \\
\hline HBD-2,-3,-4 & $3.5-4.5$ & $\begin{array}{l}\text { Colonic epithelia (and some } \\
\text { other mucosal epithelia) } \\
\text { Colonic plasma cells }\end{array}$ & $\begin{array}{l}\text { IL-1a and entero-invasive } \\
\text { bacteria }\end{array}$ \\
\hline Cryp-4 & 5.1 & Paneth cells & Uncertain \\
\hline
\end{tabular}

Table 3. Defensins in the gut of human and mouse

\subsubsection{Chemotactic activity}

Various defensins have been reported to have chemotactic activity for monocytes, $\mathrm{T}$ cells and dendritic cells. In the case of HBD-1 and HBD-2, which attract memory T cells and immature dendritic cells, the chemoattractant activity might be due to defensins binding to the chemokine receptor CCR6. Although the physiological importance of this interaction has not yet been shown, the high concentrations of HBD-2 in inflamed skin make it probable that this defensins could compete effectively with the natural CCL20, despite the higher affinity of the latter for the CCR6. Recent structural analysis of CCL20 has indicated marked similarities to HBD-2 in the putative receptor binding region of CCL20. The role of this region in the chemotactic activity of HBD-2 needs to be confirmed by mutating the aminoacid residues that are suspected to be involved in its interaction with CCR6. Human neutrophil defensins HNP1-3 have been reported to be chemotactic for monocytes, naive T cells and immature dendritic cells (Territo et al., 1989; Chertov et al., 1996; Yang et al., 1999; 2000), but a specific receptor has not yet been identified. Mouse $\beta$-defensin- 2 acted as a peptide adjuvant when it was linked to a non-immunogenic tumour antigen (Biragyn et al., 2002). This immunostimulatory activity was shown to depend on TLR-4 and its ability to induce dendritic-cell maturation. It is not yet certain how this receptor can bind with mouse $\beta$-defensin-2 as well as the many other ligands attributed to it, or whether some of 
these molecules function as efficient carriers for lipopolysaccharide, the main ligand of TLR-4.

\subsubsection{Paneth cell defensins regulate innate immune responses by NOD2 or TLRs}

TLRs which are the major pattern recognition receptors of innate immunity, by recognizing pathogen associated molecular patterns, activating the innate immune system to produce proinflammatory cytokines and defensins resist damage caused by pathogens (Elphick \& Mahida, 2005). NOD2 is a new pattern recognition molecule, participating in the antibacterial and anti-invasion effect of host cell by the identification of intracellular bacterial components. The absence of NOD2 leads to the disorder of NF- $\mathrm{KB}$, resulting in imbalance of cytokine production and defensins secretion disorders. Kobayashi et al. found that the levels of two cryptdins expression were significantly reduced when NOD2 gene mutated in mice (Kobayashi et al., 2005). NOD2 mutations have impact on Paneth cell a-defensins expression, whereas a-defensins are the main effector molecule which Paneth cells play a major role in innate immunity. Therefore, intestinal epithelium could regulate the expression of defensins secretion to activate and regulate innate immune responses by NOD or TLRs through pattern recognition receptors.

\subsubsection{Blocking ACTH activity}

Evidences have demonstrated that some defensins have a role in inhibiting the effects of adrenocorticotropic hormone (ACTH) by binding to ACTH receptor (Zhu et al., 1987, 1989; Solomon et al., 1991; Tominaga et al., 1990). Although such activity could inhibit the production of the immunosuppressive hormone cortisol, and could therefore be useful in responding to infections, the physiological role of this in vitro interaction has not yet been shown.

\subsubsection{Other activities of defensins}

It has been reported that defensins have the ability to activate nifedipine-sensitive calcium channels in mammalian cells (MacLeod et al., 1991; Bateman et al., 1996). The structural basis of this effect is not understood. Certain mouse Paneth cell defensins could promote chloride secretion, probably by forming channels in the apical membrane of epithelial cells (Lencer, et al., 1997; Merlin et al., 2001). This activity is limited to a subset of mouse Paneth cell defensins, and its structural basis is not yet known.

\subsection{Defensins in acquired Immunity}

Evidences have demonstrated that $\alpha$ - and $\beta$-defensins have chemotactic activities, indicating that defensins are involved in attracting $\mathrm{T}$ cells recycling and promoting immature dendritic cells and monocytes homing to the site of infection. HNP-1 and HNP-2 could enhance severe immune deficiency (SCID) mice $\mathrm{T}$ cell recycling (Lillard et al., 1999). Intraperitoneal administration of human neutrophil peptide (HNP) significantly increased the production of keyhole limpet henocyanin (KLH)-specific IgG1, IgG2a and IgG2b antibodies 14 days after immunization. These results indicate that defensins function as potent immune adjuvants by inducing the production of lymphokines, which promote $\mathrm{T}$ cell-dependent cellular immunity and antigen-specific Ig production, and that defensins appear to act as neutrophil-derived signals that promote adaptive immune responses (Tani et al., 2000). 
Increasing data have shown that $\beta$-defensins participate in acquired immunization mainly by chemotactic induction or direct activation of antigen presenting cells, such as dendritic cells, to activate the T cells, resulting in enhanced specific immune response ( $\mathrm{O}$ 'Neil et al., 1999). Previous study has confirmed that defensins contribute to host defense by disrupting the cytoplasmic membrane of microorganisms (Yang et al., 1999, 2000). Human a-defensins are also chemotactic for immature dendritic cells and memory $T$ cells. Human a-defensins was selectively chemotactic for cells stably transfected to express human CCR6, a chemokine receptor preferentially expressed by immature dendritic cells and memory $\mathrm{T}$ cells. The adefensin-induced chemotaxis is sensitive to pertussis toxin and inhibited by antibodies to CCR6. The binding of iodinated LARC, the chemokine ligand for CCR6, to CCR6transfected cells was competitively displaced by a-defensins. Thus, a-defensins may promote adaptive immune responses by recruiting dendritic and $\mathrm{T}$ cells to the site of microbial invasion through interaction with CCR6. In addition, defensins are also able to activate macrophages via TLR signaling and trigger acquired immune system. Evidence has shown that in cooperation with the IL-1 related protein kinase (IRAK), $\beta$-defensin- 2 as TLR4 endogenous ligand could combine with TLR4, leading to NK-KB activation and migration to the nucleus to activate cytokine gene transcription, upregulation of costimulatory molecules expression and dendritic cells maturation, thereby activate $\mathrm{T}$ cells, trigger a strong specific immune response (Biragyn et a1., 2002; Means et a1., 2000).

\section{Role of defenins in the pathogenesis of UC}

Inflammatory bowel disease (IBD) is chronic, relapsing and debilitating conditions that have significant impact on quality of life. IBD includes two main conditions, UC and Crohn's disease (CD), which are defined based on characteristic endoscopic and histological findings. UC is characterised by superficial inflammation limited to the mucosa of the colon. In contrast, $\mathrm{CD}$ is characterised by discontinuous skip lesions that can occur anywhere in the gastro-intestinal tract with transmural inflammation and non-caseating granulomas.

The pathogenesis of IBD is not clearly understood, and its presentation regarding disease localization, progression and response to therapies is unpredictable. In the intestinal tract, defensins contribute to host immunity and assist in maintaining the balance between protection from pathogens and tolerance to normal flora. However, attenuated expression of defensins compromises host immunity and hence may alter the balance toward inflammation. Altered defensins production is suggested to be an integral element in the pathogenesis of IBD (Table 4).

\begin{tabular}{|l|l|l|l|}
\hline Defensins & Ulcerative colitis & Ileal Crohn's disease & Colonic Crohn's disease \\
\hline HNP 1-4 & upregulate (infection) & Unknown & Unknown \\
\hline HD-5, HD-6 & $\begin{array}{l}\text { Upregulate, Paneth cell } \\
\text { metaplasia }\end{array}$ & $\begin{array}{l}\text { Downregulate, especially } \\
\text { NOD2 mutation paitent }\end{array}$ & $\begin{array}{l}\text { Upregulate, Paneth cell } \\
\text { metaplasia }\end{array}$ \\
\hline HBD-1 & Downregulate & Downregulate & Downregulate \\
\hline HBD-2, -3 & Upregulate (infection) & No obvious change & No obvious change \\
\hline HBD-4 & Upregulate & No obvious change & No obvious change \\
\hline Cryp-2 & Upregulate & Unknown & Unknown \\
\hline Cryp-4 & Unknown & Unknown & Downregulate \\
\hline
\end{tabular}

Table 4. Defensins expression in ulcerative colitis, and colonic and ileal Crohn's disease 


\section{1 $\alpha$-defensins in UC \\ 6.1.1 Paneth cell-derived $\alpha$-defensins in UC}

a-defensins are highly expressed by Paneth cells (Fig. 1). These cells are located at the base of the crypts of Lieberkühn and are distributed from the duodenum to the ileum. Their location in the crypts suggests an essential role of protecting the epithelial stem cells, located in close proximity. Paneth cells are filled with large apically located granules (Fig. 1A) and have ultrastructural hallmarks (an extensive endoplasmic reticulum and well-developed Golgi) of prototypical secretory cells. The development of small intestine gland is imperfect in newborn BALB/c mice, and no Paneth cells were seen 4 days before. However, Paneth cells could be detected in small intestine gland 6 days after birth (Fig. 1C). In addition to a-defensins, human Paneth cells also secrete lysozyme, Reg $3 \gamma$, and phospholipase A2 (Ouellette \& Bevins, 2001). Of these antimicrobials, the adefensins are the most abundant. In addition, mouse Paneth cells also express numerous cryptdin-related peptides (Fig. 1B) and angiogenin (Ouellette \& Bevins, 2001; Hornef et al., 2004).

Numerous data have proven that intestinal luminal microbes play an important role in the pathogenesis of IBD (Janowitz et al., 1998; Sartor, 2001; Marteau et al., 2004; Strober et al., 2007). NOD2, the aforementioned intracellular peptidoglycan receptor for muramyl dipeptide is the first susceptibility gene identified for IBD (Hugot et al., 2001; Ogura et al., 2001). Mutations in NOD2 are likely responsible for the genetic predisposition to disease in approximate one third of patients with CD, especially for ileal disease (Bonen \& Cho, 2003; Hugot 2004). NOD2 is expressed in macrophages and Paneth cells. Since Paneth cell antimicrobials may affect the microbial composition of the small intestine, deleterious changes in the bacterial microbiota that result from altered Paneth cell function might contribute to the pathogenesis of IBD (Ouellette \& Bevins, 2001; Fellermann et al., 2003).

Wehkamp et al. have reported that low levels of Paneth cell a-defensins mRNA and protein are present in inflamed ileum of CD patients as compared to non-IBD controls (Wehkamp et al., 2004, 2005). Interestingly, the specific decrease in a-defensins is more pronounced in CD patients with NOD2 gene mutation. Consistent with this, Kobayashi et al. reported a decrease expression of Paneth cell a-defensins (cryptdin) and cryptdin related sequences in NOD2-knockout mice (Kobayashi et al., 2005). As compared to wild-type controls, the NOD2-knockout mice are more susceptible to gastric, but not systemic, challenges with the Gram-positive bacterium Listeria monocytogenes. The decreased expression of Paneth cell antimicrobials in the NOD2-knockout mice is proposed to underlie the increased susceptibility.

\subsection{2 $\alpha$-defensins by colonic Paneth cells}

Evidences have shown that HD-5 and HD-6 are not present in normal colonic mucosa. However, Cunliffe et al. detected HD5 in the colonic crypt region of IBD samples (Cunliffe et al., 2001). The appearance of these defensins is due to the phenomenon of Paneth cell metaplasia during colonic inflammation. HD-5 mRNA expression is enhanced in both idiopathic and nonidiopathic inflammatory states of the large bowel, whereas HD-6 is specifically related to CD and UC. Immunohistochemical staining has confirmed that the presence of HD-5 in colonic epithelium may be of importance in maintaining the mucosal barrier and controlling microbial invasion in IBD (Yamaguchi et al., 2009). 

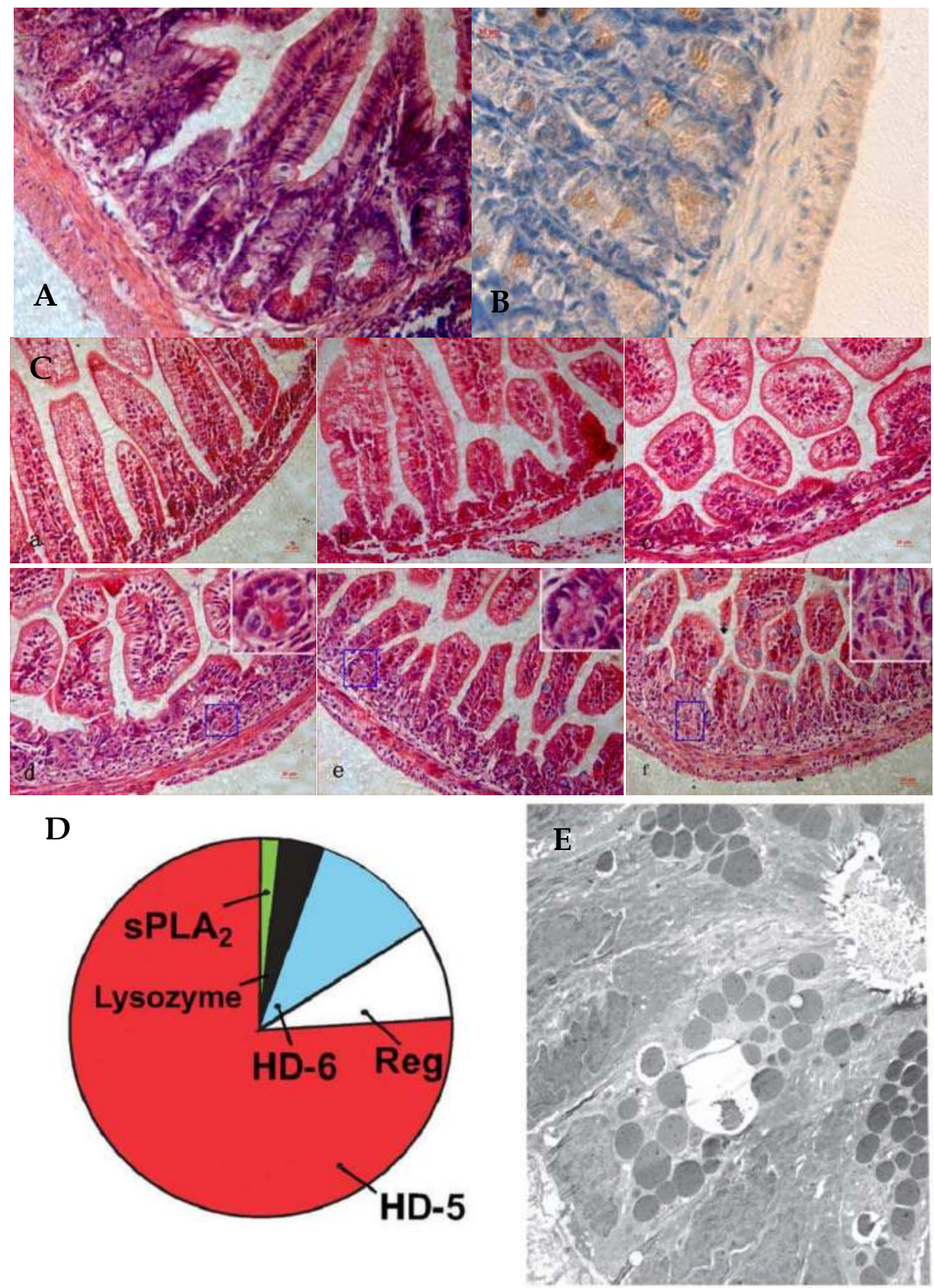

Fig. 1. Paneth cell granules contain a-defensins

A: Hematoxylin-eosin stain of small intestinal crypt shows Paneth cell granules (Bright Red) containing a-defensins in ileum of BALB/c mice. Abundant large secretory vesicles of 
Paneth cells are adjacent to the crypt lumen. Scale bar $=20 \mu \mathrm{m}$.

B: Immunohistochemical staining demonstrates Cryptdins-4 in the granules of Paneth cell in the ileum crypts of BALB/c mice. Scale bar $=10 \mu \mathrm{m}$.

C: The Paneth cells in intestine of newborn BALB/c mice. The development of small intestine gland is imperfect in newborn BALB/c mice, and no Paneth cells were seen 4 days before. However, Paneth cells could be detected in small intestine gland 6 days after birth. a: duodenum, 4 days; b: jejunum, 4 days; c: ileum, 4 days; $d$ : duodenum, 10 days; e: jejunum, 10 days; f: ileum, 10 days. Scale bar $=20 \mu \mathrm{m}$

D: Real-time PCR analysis of mRNA encoding Paneth cell a-defensins (HD-5 and HD-6) antimicrobial peptides in human ileum.

E: Immunogold electron microscopy localizes HD5 to Paneth cell secretory granules.

Transmission electron micrograph of human ileum crypt with immunogold staining for HD5. Defensin-rich granules were found exclusively in Paneth cells

\subsubsection{Other $\alpha$-defensins in the gut}

Human HNP-1, -2, -3, and -4 have been found to be present in the granules of polymorphonuclear cells and intestinal epithelial cells, where they participate in systemic innate immunity (Cunliffe, 2003). Cunliffe and colleagues have observed that the mRNA levels of HNP-1, -2 , and -3 are significantly increased in inflamed mucosa of IBD patients compared with controls (Cunliffe, 2003), indicating that a-defensins are also involved in the pathogenesis of IBD.

Evidences have shown that expression of HNP-1, -2 and -3 mRNA is highly increased in inflamed colon of UC patients than in healthy controls. Further research also proved that the expression levels of HNP1-3 mRNA, NO and MDA is significantly higher in colonic mucosa of UC patients than in that of normal controls. The expression of HNP-1, -2 , and -3 mRNA is correlated with the levels of NO and MDA in the inflamed mucosa in UC patients, the induction of HNP-1, -2 , and -3 is involved in the process of inflammation and damage of UC. HNP-1, -2, and -3, NO and MDA might have synergistic effects on colonic inflammation (Cunliffe et al., 2002, 2003). These HNPs are also significantly increased in sera of IBD patients compared with controls, and being significantly correlated with CD activity index, peripheral white blood cell counts, serum CRP values and TNF-a levels (Yamaguchi et al., 2009).

\section{2 $\beta$-defensins in UC}

\subsubsection{Inducible $\beta$-defensins in UC}

Evidences have shown that expression of the inducible $\beta$-defensins is significantly increased in inflamed mucosal of UC patients compared with controls. Moreover, HBD-2 expression has also been found to be significantly increased in inflamed colon of UC patients compared with that in controls and CD patients (Wehkamp et al., 2002). In mucosal biopsies, HBD-1 expression is marginally decreased in both CD and UC patients, while HBD-2 is increased exclusively in UC but not in CD. Interestingly, expression of HBD-3 is found to be strongly correlated with HBD-2 in UC (Wehkamp et al., 2003).

\subsubsection{Colonic $\boldsymbol{\beta}$-defensins}

It has been reported that epithelial cells and plasma cells in the lamina propria of colon express HBD. Importantly, expression of HBD-1 is constitutively, while expression of HBD- 
$2,-3$, and -4 is induced by various inflammatory and bacterial stimuli. The pathway responsible for induction of $\mathrm{HBD}$ is not completely understood, however it has been presumed that NOD2 signaling is involving in triggering transcription expression of HBD genes (Voss et al., 2006). Colonic plasma cells also express HBD-2, -3 and -4 , but it is unclear whether this expression is constitutive or inducible (Rahman et al., 2007).

Previous studies have found that colonic mucosa HBD-1 expression is decreased in UC, and this reduction may result in the decrease of antibacterial activity of mucosal immune system, leading to bacterial invasion secondary inflammatory response. Further studies suggest that defensins deficiency is due to mucosal surface destruction as a result of inflammatory changes, indicating that reduced defensins expression is a symptom of the disease and not the cause (Ramasundara et al., 2009).

Relative low level of HBD-2 expression is found in epithelial cells of normal colon, but significantly increased in inflamed colon ( $\mathrm{O}^{\prime} \mathrm{Neil}$ et al., 1999). In feces from healthy control individuals, low levels of HBD-2 were detectable, which are also markedly increased under inflammatory conditions (Kapel et al., 2009). In a study by Wehkamp and associates, HBD-2 mRNA was detectable in only $18 \%$ of control biopsies compared to $34 \%$ in CD and $53 \%$ in UC (Wehkamp et al., 2002). In addition, there was increased HBD-2 expression in inflamed compared to non-inflamed areas of CD patients and similarly in UC (Wehkamp et al., 2003). $\mathrm{O}^{\prime}$ Neil and colleagues also demonstrated that HBD-2 mRNA was expressed by colonic epithelial cells in response to stimulation by proinflammatory mediators IL-1a and enteroinvasive bacteria (O'Neil et al, 1999; Fahlgren et al, 2003). In addition, HBD-3 and HBD-4 are expressed minimally in normal intestinal epithelium, and that there was no difference in expression for patients with colonic CD. In contrast, there was a significant increase of HBD3 and HBD-4 in UC (Fellermann et al., 2006; 2007).

Overall, HBD-1 is constitutively expressed in normal intestinal epithelial cells and play foundational defense roles in the mucosal immune, while HBD-2, -3 and -4 could be inducted to express in inflamed mucosa of UC patients and play a defense role in inflammation response.

\section{Defensins therapy in UC}

Imbalance of intestinal mucosal immunity is an important condition for the pathogenesis of UC, and the defensins is an important factor to maintain the immune response in intestinal mucosa. Defensins play an important role in the prevention and treatment of mucosal inflammation. Consistent with this, evidences have proven that defensins could inhibit the development of neonatal colitis in mice caused by Escherichia coli (Sherman et al., 2005). Moreover, defensins also have certain effects on the inhibition of bacterial translocation and control of intestinal infection, which may substitute for antibiotics in the prevention of bacterial infection and some inflammatory diseases. Therefore, monitoring of defensins will help us to evaluate the severity of inflammation (Hiratsuka et al., 1998). A new approach using defensins therapy may shed some light on management of infectious and inflammatory conditions such as UC. HBD-1-expressing Escherichia coli clone has been generated, and defensins protein with biological activity is purified (Cipakova et al., 2004, 2005). HBD-2 gene was also cloned from the lesions of human condyloma acuminatum, and an expression vector was constructed and transformed into Escherichia coli (Fang et al., 2002). These approaches may allow us to have a clinical trial in the treatment of UC in the future. 


\section{Outlook}

Since innate immune responses in the gut are directed against luminal bacteria, a defect in the expression and/or function of defensins could give rise to an increase in frequency and severity of intestinal infections. Such a deficiency could lead to gradual bacterial invasion, inflammation and a loss of tolerance to gut bacteria. Although this presumes that a defensins deficiency is a primary event in the pathogenesis of IBD, it also possible that the deficiency is a secondary event, occurring as a consequence of the disease. The pathogenesis of UC is not clear, but increasing data have suggested that the abnormalities of intestinal mucosal immune system play a decisive role in the occurrence and development, while the intestinal defenses play an important role in maintaining the balance of mucosal immune. Defensins function as the effective and regulatory molecules of the immune system in the gut. Further study on relationship between defenses and UC will be conducive to understand the pathogenesis of UC, but also provide new approaches for the treatment.

\section{References}

Andreu P, Colnot S, Godard C, Gad S, Chafey P, Niwa-Kawakita M, Laurent-Puig P, Kahn A, Robine S, Perret C, Romagnolo B. (2005). Crypt-restricted proliferation and commitment to the Paneth cell lineage following Apc loss in the mouse intestine. Development, Vol.132, No.6, (March 2005), pp. 1443-1451, ISSN 09501-1991

Aono S, Li C, Zhang G, Kemppainen RJ, Gard J, Lu W, Hu X, Schwartz DD, Morrison EE, Dykstra C, Shi J. (2006). Molecular and functional characterization of bovine betadefensin-1. Veterinary Immunoologyl Immunopathoologyl, Vol.113, No.1-2, (September 2006), pp. 181-190, ISSN 0165-2427

Ayabe T, Satchell DP, Pesendorfer P, Tanabe H, Wilson CL, Haqen SJ, Ouellette AJ. (2002). Activation of Paneth cell alpha-defensins in mouse small intestine. Journal of Biological Chemestry, Vol.277, No.7, (February 2002), pp. 5219-5228, ISSN 0021-9258

Ayabe T, Satchell DP, Wilson CL, Parks WC, Selsted ME, Ouellette AJ. (2000). Secretion of microbicidal alpha-defensins by intestinal Paneth cells in response to bacteria. Nature Immunology, Vol.1, No.2, (Auguest 2000), pp. 113-118, ISSN 1529-2908

Bateman A, MacLeod RJ, Lembessis P, Hu J, Esch F, Solomon S. (1996). The isolation and characterization of a novel corticostatin/defensin-like peptide from the kidney. Journal of Biological Chemestry, Vol.271, No.18, (May 1996), pp. 10654-10659, ISSN 0021-9258

Batlle E, Henderson JT, Beghtel H, van den Born MM, Sancho E, Huls G, Meeldijk J, Robertson J, van de Wetering M, Pawson T, Clevers H. (2002). Beta-catenin and TCF mediate cell positioning in the intestinal epithelium by controlling the expression of EphB/ephrinB. Cell, Vol.111, No.2, (Octomber 2002), pp.251-263, ISSN 0092-8674

Bensch KW, Raida M, Mägert HJ, Schulz-Knappe P, Forssmann WG. (1995). hBD-1: a novel beta-defensin from human plasma. FEBS Letters, Vol.368, No.2, (July 1995), pp. 331335, ISSN 0014-5793

Bevins CL, Jones DE, Dutra A, Schaffzin J, Muenke M. (1996). Human enteric defensin genes: chromosomal map position and a model for possible evolutionary relationships. Genomics, Vol.31, No.1, (January 1996), pp. 95-106, ISSN 0888-7543 
Bevins CL. The Paneth cell and the innate immune response. (2004). Current Opinion in Gastroenterology, Vol.20, No.6, (November 2004), pp. 572-580, ISSN 0267-1379

Biragyn A, Ruffini PA, Leifer CA, Klyushnenkova E, Shakhov A, Chertov O, Shirakawa AK, Farber JM, Segal DM, Oppenheim JJ, Kwak LW. (2002). Toll-like receptor 4dependent activation of dendritic cells by beta-defensin 2. Science, Vol.298, No.5595, (November 2002), pp. 1025-1029, ISSN 0036-8075

Boman HG. Peptide antibiotics and their role in innate immunity. (1995). Annual Review of Immunology, Vol.13, (no date), pp. 61-92, ISSN 0732-0582

Bonen DK, Cho JH.(2003). The genetics of inflammatory bowel disease. Gastroenterology, Vol.124, No.2, (Feburary 2003), pp. 521-536, ISSN 0016-5085

Chertov O, Michiel DF, Xu L, Wang JM, Tani K, Murphy WJ, Longo DL, Taub DD, Oppenheim JJ. (1996). Identification of defensin-1, defensin-2, and CAP37/azurocidin as T-cell chemoattractant proteins released from interleukin-8stimulated neutrophils. Journal of Biological Chemestry, Vol.271, No.6, (February 1996), pp. 2935-2940, ISSN 0021-9258

Cipakova I, Hostinová E, Gasperík J, Velebný V. (2004). High-level expression and purification of a recombinant hBD-1 fused to LMM protein in Escherichia coli. Protein Expression and Purification, Vol.37, No.1, (September 2004), pp. 207-212, ISSN1046-5928

Cipakova I, Hostinová E. (2005). Production of the human-beta-defensin using Saccharomyces cerevisiae as a host. Protein Peptide Letters, Vol.12, No.6, (Auguest 2005), pp. 551-554, ISSN 0929-8665

Cole AM, Hong T, Boo LM, Nguyen T, Zhao C, Bristol G, Zack JA, Waring AJ, Yang OO, Lehrer RI. (2002). Retrocyclin: a primate peptide that protects cells from infection by T- and M-tropic strains of HIV-1. Proceedings of the National Academy of Sciences USA, Vol.99, No.4, (Feburary 2002), pp. 1813-1818, ISSN 1091-6490

Cunliffe RN, Kamal M, Rose FR, James PD, Mahida YR. (2002). Expression of antimicrobial neutrophil defensins in epithelial cells of active inflammatory bowel disease mucosa. Journal of Clinical Pathology, Vol.55, No.4, (Aprial 2002), pp. 298-304, ISSN 2153-3539

Cunliffe RN, Rose FR, Keyte J, Abberley L, Chan WC, Mahida YR. (2001). Human defensin 5 is stored in precursor form in normal Paneth cells and is expressed by some villous epithelial cells and by metaplastic Paneth cells in the colon in inflammatory bowel disease. Gut, Vol.48, No.2, (Feburary 2001), pp. 176-185, ISSN 00017-5749

Cunliffe RN. (2003). Alpha-defensins in the gastrointestinal tract. Molecular Immunology, Vol.40, No.7, (November 2003), pp. 463-467,ISSN 0161-5890

Diamond G, Zasloff M, Eck H, Brasseur M, Maloy WL, Bevins CL. (1991). Tracheal antimicrobial peptide, a cysteine-rich peptide from mammalian tracheal mucosa: peptide isolation and cloning of a cDNA. Proceedings of the National Academy of Sciences USA, Vol.88, No.1, (May 1991), pp. 3952-3956, ISSN 1091-6490

Elphick DA, Mahida YR. (2005). Paneth cells: their role in innate immunity and inflammatory disease. Gut, Vol.54, No.12, (July 2005), pp. 1802-1809, ISSN 000175749

Ericksen B, Wu Z, Lu W, Lehrer RI. (2005). Antibacterial activity and specificity of the six human (alpha)-defensins. Antimicrobial Agents Chemotherapy, Vol.49, No.1, (January 2005), pp. 269-275, ISSN 0066-4804 
Fahlgren A, Hammarstrom S, Danielsson A, Hammarstrom ML. (2003). Increased expression of antimicrobial peptides and lysozyme in colonic epithelial cells of patients with ulcerative colitis. Clinical Experimenal Immunology, Vol.131, No.1, (January 2003), pp. 90-101, ISSN 0009-9104

Fahlgren A, Hammarstrom S, Danielsson A, Hammarstrom ML. (2004). beta-Defensin-3 and -4 in intestinal epithelial cells display increased mRNA expression in ulcerative colitis. Clinical Experimenal Immunology, Vol.137, No.2, (Auguest 2004), pp. 379-385, ISSN 0009-9104

Fang X, Peng L, Xu Z, Wu J, Cen P. (2002). Cloning and expression of human beta-defensin-2 gene in Escherichia coli. Protein Peptide Letters, Vol.9, No.1, (Feburary 2002), pp. 3137, ISSN 0929-8665

Fellermann K, Stange DE, Schaeffeler E, Schmalzl H, Wehkamp J, Bevins CL, Reinisch W, Teml A, Schwab M, Lichter P, Radlwimmer B, Stange EF. (2006). A chromosome 8 gene-cluster polymorphism with low human beta-defensin 2 gene copy number predisposes to Crohn disease of the colon. American Journal of Human Genetics, Vol.79, No.3, (Semptember 2006), pp. 439-448, ISSN 0002-9297

Fellermann K, Wehkamp J, Herrlinger KR, Stange EF. (2003). Crohn's disease: a defensin deficiency syndrome? European Joournal of Gastroenterology and Hepatology, Vol.15, No.6, (June 2003), pp. 627-634, ISSN 0954-691X

Ganz T. Defensins: antimicrobial peptides of innate immunity. (2003). Nature Review of Immunology, Vol.3, No.9, (September 2003), pp. 710-720, ISSN 1474-1733

Garcia AE, Osapay G, Tran PA, Yuan J, Selsted ME. (2008). Isolation, synthesis, and antimicrobial activities of naturally occurring theta-defensin isoforms from baboon leukocytes. Infection and Immunity, Vol.76, No.12, (December 2008), pp. 5883-5891, ISSN 0019-9567

Garcia AE, Selsted ME. (2008). Olive baboon theta-defensins. FASEB Journal, Vol.22, (April 2008), Meeting Abstracts, pp. 673.11, ISSN 0892-6638

Garcia JR, Krause A, Schulz S, Rodríguez-Jiménez FJ, Klüver E, Adermann K, Forssmann U, Frimpong-Boateng A, Bals R, Forssmann WG. (2001). Human beta-defensin 4: a novel inducible peptide with a specific salt-sensitive spectrum of antimicrobial activity. FASEB Journal, Vol.15, No.10, (Auguest 2001), pp. 1819-1821, ISSN 08926638

Ghosh D, Porter E, Shen B, Lee SK, Wilk D, Drazba J, Yadav SP, Crabb JW, Ganz T, Bevins CL. (2002). Paneth cell trypsin is the processing enzyme for human defensin-5. Nature Immunology, Vol.3, No.6, (June 2002), pp. 583-590, ISSN 1529-2908

Harder J, Bartels J, Christophers E, Schröder JM. (1997). A peptide antibiotic from human skin. Nature, Vol.387, No.6636, (June 1997), pp. 861, ISSN 0028-0836

Harder J, Bartels J, Christophers E, Schroder JM. (2001). Isolation and characterization of human beta-defensin-3, a novel human inducible peptide antibiotic. Journal of Biological Chemistry, Vol.276, No.8, (Feburary 2001), pp. 5707-5713, ISSN 0021-9258

Harder J, Siebert R, Zhang Y, Matthiesen P, Christophers E, Schlegelberger B, Schröder JM. (1997). Mapping of the gene encoding human beta-defensin-2 (DEFB2) to chromosome region 8p22-p23.1. Genomics, Vol.46, No.3, (December 1997), pp. 472475, ISSN 0888-7543

He XC, Zhang J, Tong WG, Tawfik O, Ross J, Scoville DH, Tian Q, Zeng X, He X, Wiedemann LM, Mishina Y, Li L. (2004). BMP signaling inhibits intestinal stem cell 
self-renewal through suppression of Wnt-beta-catenin signaling. Nature Genetics, Vol.36, No.10, (October 2004), pp. 1117-1121, ISSN 1061-4036

Hill CP, Yee J, Selsted ME, Eisenberg D. (1991). Crystal structure of defensin HNP-3, an amphiphilic dimer: mechanisms of membrane permeabilization. Science, Vol.251, No.5000, (March 1991), pp. 1481-1485, ISSN 0036-8075

Hiratsuka T, Nakazato M, Date Y, Ashitani J, Minematsu T, Chino N, Matsukura S. (1998). Identifiation of human beta-defensin-2 in respiratory tract and plasma and its increase in bacterial pneumonia. Biochemical Biophysical Research Communications, Vol.249, No.3, (Auguest 1998), pp. 943-947, ISSN 0006-291X

Hornef MW, Pütsep K, Karlsson J, Refai E, Andersson M. (2004). Increased diversity of intestinal antimicrobial peptides by covalent dimer formation. Nature Immunology, Vol.5, No.8, (Auguest 2004), pp. 836-843, ISSN 1529-2908

Hugot JP, Chamaillard M, Zouali H, Lesage S, Cézard JP, Belaiche J, Almer S, Tysk C, O'Morain CA, Gassull M, Binder V, Finkel Y, Cortot A, Modigliani R, Laurent-Puig P, Gower-Rousseau C, Macry J, Colombel JF, Sahbatou M, Thomas G. (2001). Association of NOD2 leucine-rich repeat variants with susceptibility to Crohn's disease. Nature, Vol.411, No.6837, (May 2001), pp. 599-603, ISSN 0028-0836

Hugot JP. (2004). Genetic origin of IBD. Inflammatory Bowel Diseases, Suppl 1, (Feburary 2004), pp. S11-S15,ISSN 1078-0998

Huttner KM, Selsted ME, Ouellette AJ. (1994). Structure and diversity of themurine cryptdin gene family. Genomics, Vol.19, No.3, (Feburary 1994), pp. 448-453, ISSN 0888-7543

Janowitz HD, Croen EC, Sachar DB. (1998). The role of the fecal stream in Crohn's disease: an historical and analytic review. Inflammatory Bowel Diseases, Vol.4, No.1, (Feburary 1998), pp. 29-39, ISSN 1078-0998

Jones DE, Bevins CL. (1992). Paneth cells of the human small intestine express an antimicrobial peptide gene. Journal of Biological Chemistry, Vol.267, No.32, (November 1992), pp. 23216-23225, ISSN 0021-9258

Jones DE, Bevins CL. (1993). Defensin-6 mRNA in human Paneth cells: implications for antimicrobial peptides in host defense of the human bowel. FEBS Letters, Vol.315, No.2, (January 1993), pp. 187-192, ISSN 0014-5793

Kapel N, Benahmed N, Morali A, Svahn J, Canioni D, Goulet O, Ruemmele FM. (2009). Fecal beta-defensin-2 in children with inflammatory bowel diseases. Journal of Pediatric Gastroenterology and Nutrition, Vol.48, No.1, (January 2009), pp. 117-120, ISSN 02772116

Kelly P, Feakins R, Domizio P, Murphy J, Bevins C, Wilson J, McPhail G, Poulsom R, Dhaliwal W. (2004). Paneth cell granule depletion in the human small intestine under infective and nutritional stress. Clinical Experimental Immunology, Vol.135, No.2, (Feburary 2004), pp. 303-309, ISSN 0009-9104

Kobayashi KS, Chamaillard M, Ogura Y, Henegariu O, Inohara N, Nuñez G, Flavell RA. (2005). Nod2-dependent regulation of innate and adaptive immunity in the intestinal tract. Science, Vol.307, No.5710, (Feburary 2005), pp. 731-734, ISSN 00368075

Lala S, Ogura Y, Osborne C, Hor SY, Bromfield A, Davies S, Ogunbiyi O, Nuñez G, Keshav S. (2003). Crohn's disease and the NOD2 gene: a role for paneth cells. Gastroenterology, Vol.125, No.1, (July 2003), pp. 47-57, ISSN 0016-5085 
Lehrer RI, Ferrari LG, Patterson-Delafield J, Sorrell T. (1980). Fungicidal activity of rabbit alveolar and peritoneal macrophages against Candida albicans. Infection and Immunity, Vol.28, No.3, (June 1980), pp. 1001-1008, ISSN 0019-9567

Lehrer RI. (2004). Primate defensins. Nature Reviews Microbiology, Vol.2, No.9, (Semptember 2004), pp. 727-738, ISSN 1740-1526

Leonova L, Kokryakov VN, Aleshina G, Hong T, Nguyen T, Zhao C, Waring AJ, Lehrer RI. (2001). Circular minidefensins and posttranslational generation of molecular diversity. Journal of Leukocyte Biology, Vol.70, No.3, (September 2001), pp. 461-464, ISSN 0741-5400

Lillard JW Jr, Boyaka PN, Chertov O, Oppenheim JJ, McGhee JR. (1999). Mechanisms for induction of acquired host immunity by neutrophil peptide defensins. Proceedings of the National Academy of Sciences USA, Vol.96, No.2, (January 1999), pp. 651-656, ISSN 1091-6490

Liu L, Ganz T. (1995). The pro region of human neutrophil defensin contains a motif that is essential for normal subcellular sorting. Blood, Vol.85, No.4, (Feburary 1995), pp. 1095-1103, ISSN 0006-4971

MacLeod RJ, Hamilton JR, Bateman A, Belcourt D, Hu J, Bennett HP, Solomon S. (1991). Corticostatic peptides cause nifedipine-sensitive volume reduction in jejunal villus enterocytes. Proceedings of the National Academy of Sciences USA, Vol.88, No.2, (January 1991), pp. 552-556, ISSN 1091-6490

Maisetta G, Batoni G, Esin S, Raco G, Bottai D, Favilli F, Florio W, Campa M. (2005). Susceptibility of Streptococcus mutans and Actinobacillus actinomycetemcomitans to bactericidal activity of human beta-defensin3 in biological fluids. Antimicrobial Agents Chemotherapy, Vol.49, No.3, (March 2005), pp. 1245-1248, ISSN 0066-4804

Mallow EB, Harris A, Salzman N, Russell JP, DeBerardinis RJ, Ruchelli E, Bevins CL. (1996). Human enteric defensins: gene structure and developmental expression. Journal of Biological Chemistry, Vol.271, No.8, (Feburary 1996), pp. 4038-4045, ISSN 0021-9258

Marteau P, Lepage P, Mangin I, Suau A, Doré J, Pochart P, Seksik P. (2004). Review article: gut flora and inflammatory bowel disease. Alimentary Pharmacology Therapeutics, Suppl 4, (October 2004), pp. 18-23, ISSN 0269-2813

Means TK, Golenbock DT, Fenton MJ. (2000). The biology of Toll-like receptors. Cytokine Growth Factor Review, Vol.11, No.3, (September 2000), pp. 219-232, ISSN 1359-6101

Merlin D, Yue G, Lencer WI, Selsted ME, Madara JL. (2001). Cryptdin-3 induces novel apical conductance(s) in Cl- secretory, including cystic fibrosis, epithelia. American Journal of Physiology-Cell Physiology, Vol.280, No.2, (Feburary 2001), pp. C296-302, ISSN 0363-6143

Nguyen TX, Cole AM, Lehrer RI. (2003). Evolution of primate theta-defensins: a serpentine path to a sweet tooth. Peptides, Vol.24, No.11, (November 2003), pp. 1647-1654, ISSN 0196-9781

Ogura Y, Bonen DK, Inohara N, Nicolae DL, Chen FF, Ramos R, Britton H, Moran T, Karaliuskas R, Duerr RH, Achkar JP, Brant SR, Bayless TM, Kirschner BS, Hanauer SB, Nuñez G, Cho JH. (2001). A frameshift mutation in NOD2 associated with susceptibility to Crohn's disease. Nature, Vol.411, No.6837, (May 2001), pp. 603-606, ISSN 0028-0836

O'Neil DA, Porter EM, Elewaut D, Anderson GM, Eckmann L, Ganz T, Kagnoff MF. (1999). Expression and regulation of the human beta-defensins hBD-1 and hBD-2 in 
intestinal epithelium. Journal of Immunology, Vol.163, No.12, (December 1999), pp. 6718-6724, ISSN 0022-1767

Ouellette AJ, Bevins CL. (2001). Paneth cell defensins and innate immunity of the small bowel. Inflammatory Bowel Diseases, Vol.7, No.1, (Feburary 2001), pp. 43-50,ISSN 1078-0998

Ouellette AJ, Cordell B. (1988). Accumulation of abundant messenger ribonucleic acids during postnatal development of mouse small intestine. Gastroenterology, Vol.94, No.1, (January 1988), pp. 114-121, ISSN 0016-5085

Ouellette AJ, Darmoul D, Tran D, Huttner KM, Yuan J, Selsted ME. (1999). Peptide localization and gene structure of cryptdin 4, a differentially expressed mouse Paneth cell alpha-defensin. Infection and Immunity, Vol.67, No.12, (December 1999), pp. 6643-6651, ISSN 0019-9567

Ouellette AJ, Greco RM, James M, Frederick D, Naftilan J, Fallon JT. (1989a). Developmental regulation of cryptdin, a corticostatin/defensin precursor mRNA in mouse small intestinal crypt epithelium. Journal of Cell Biology, Vol.108, No.5, (May 1989), pp. 1687-1695, ISSN 0021-9525

Ouellette AJ, Lualdi JC. (1990). A novel mouse gene family coding for cationic, cysteine-rich peptides. Regulation in small intestine and cells of myeloid origin. Journal of Biological Chemistry, Vol.265, No.17, (June 1990), pp. 9831-9837, ISSN 0021-9258

Ouellette AJ, Pravtcheva D, Ruddle FH, James M. (1989b). Localization of the cryptdin locus on mouse chromosome 8. Genomics, Vol.5, No.2, (Auguest 1989), pp. 233-239, ISSN 0888-7543

Ouellette AJ, Satchell DP, Hsieh MM, Hagen SJ, Selsted ME. (2000). Characterization of luminal paneth cell alpha-defensins in mouse small intestine. Attenuated antimicrobial activities of peptides with truncated amino termini. Journal of Biological Chemistry, Vol.275, No.43, (October 2000), pp. 33969-33973, ISSN 00219258

Ouellette AJ, Selsted ME. (1996). Paneth cell defensins: endogenous peptide components of intestinal host defense. FASEB Journal, Vol.10, No.11, (September 1996), pp. 12801289, ISSN 0892-6638

Ouellette AJ. (2005). Paneth cell alpha-defensins: peptide mediators of innate immunity in the small intestine. Springer Seminars in Immunopathology, Vol.27, No.2, (September 2005), pp. 133-146, ISSN 1863-2300

Ouellette AJ. (2006). Paneth cell alpha-defensin synthesis and function. Current Topics in Microbiology Immunology, Vol.306, (no date), pp. 1-25, ISSN 0070-217X

Owen SM, Rudolph DL, Wang W, Cole AM, Waring AJ, Lal RB, Lehrer RI. (2004). RC-101, a retrocyclin-1 analogue with enhanced activity against primary HIV type 1 isolates. AIDS Research Human Retroviruses, Vol.20, No.11, (November 2004), pp. 1157-1165, ISSN 0889-2229

Pardi A, Zhang XL, Selsted ME, Skalicky JJ, Yip PF. (1992). NMR studies of defensin antimicrobial peptides. 2. Three-dimensional structures of rabbit NP-2 and human HNP-1. Biochemistry, Vol.31, No.46, (November 1992), pp. 11357-11364, ISSN 00062960

Patil A, Hughes AL, Zhang G. (2004). Rapid evolution and diversification of mammalian alpha-defensins as revealed by comparative analysis of rodent and primate genes. Physiology Genomics, Vol.20, No.1, (December 2004), pp. 1-11, ISSN 1094-8341 
Pinto D, Clevers H. (2005). Wnt control of stem cells and differentiation in the intestinal epithelium. Experimental Cell Research, Vol.306, No.2, (June 2005), pp. 357-363, ISSN 0014-4827

Porter EM, Liu L, Oren A, Anton PA, Ganz T. (1997b). Localization of human intestinal defensin 5 in Paneth cell granules. Infection and Immunity, Vol.65, No.6, (June 1997), pp. 2389-2395, ISSN 0019-9567

Porter EM, van Dam E, Valore EV, Ganz T. (1997a). Broad-spectrum antimicrobial activity of human intestinal defensin 5. Infection and Immunity, Vol.65, No.6, (June 1997), pp. 2396-2401, ISSN 0019-9567

Putsep K, Axelsson LG, Boman A, Midtvedt T, Normark S, Boman HG, Andersson M. (2000). Germ-free and colonized mice generate the same products from enteric prodefensins. Journal of Biological Chemistry, Vol.275, No.51, (December 2000), pp. 40478-40482, ISSN 0021-9258

Qu XD, Lloyd KC, Walsh JH, Lehrer RI. (1996). Secretion of type II phospholipase A2 and cryptdin by rat small intestinal Paneth cells. Infection and Immunity, Vol.64, No.12, (December 1996), pp. 5161-5165, ISSN 0019-9567

Rahman A, Fahlgren A, Sitohy B, Baranov V, Zirakzadeh A, Hammarström S, Danielsson A, Hammarström ML. (2007). Beta-defensin production by human colonic plasma cells: a new look at plasma cells in ulcerative colitis. Inflammatory Bowel Diseases, Vol.13, No.7, (July 2007), pp. 847-855,ISSN 1078-0998

Ramasundara M, Leach ST, Lemberg DA, Day AS. (2009). Defensins and inflammation: the role of defensins in inflammatory bowel disease. Journal of Gastroenterology and Hepatology, Vol.24, No. 2, (Feburary 2009), pp. 202-208, ISSN 0815-9319

Rumio C, Besusso D, Palazzo M, Selleri S, Sfondrini L, Dubini F, Ménard S, Balsari A. (2004). Degranulation of Paneth cells via toll-like receptor 9. American Journal of Pathology, Vol.165, No.2, (Auguest 2004), pp. 373-381, ISSN 0002-9440

Salzman NH, Chou MM, de Jong H, Liu L, Porter EM, Paterson Y. (2003). Enteric Salmonella infection inhibits Paneth cell antimicrobial peptide expression. Infection and Immunity, Vol.71, No.3, (March 2003), pp. 1109-1115, ISSN 0019-9567

Salzman NH, Underwood MA, Bevins CL. (2007). Paneth Cells, Defensins, and the commensal microbiota: A hypothesis on intimate interplay at the intestinal mucosa. Seminars in Immunology, Vol.19, No.2, (April 2007), pp. 19: 70-83, ISSN 1044-5323

Sartor RB. (2001). Intestinal microflora in human and experimental inflammatory bowel disease. Current Opinion in Gastroenterology, Vol.17, No.4, (July 2001), pp. 324-330, ISSN 0267-1379

Satoh Y, Habara Y, Ono K, Kanno T. (1995). Carbamylcholine- and catecholamine-induced intracellular calcium dynamics of epithelial cells in mouse ileal crypts. Gastroenterology, Vol.108, No.5, (May 1995), pp. 1345-1356, ISSN 0016-5085

Sawai MV, Jia HP, Liu L, Aseyev V, Wiencek JM, McCray PB Jr, Ganz T, Kearney WR, Tack BF. (2001). The NMR structure of human beta-defensin-2 reveals a novel alphahelical segment. Biochemistry, Vol.40, No.13, (April 2001), pp. 3810-3816, ISSN 00062960

Selsted ME, Miller SI, Henschen AH, Ouellette AJ. (1992). Enteric defensins: antibiotic peptide components of intestine host defense. Journal of Cell Biology, Vol.118, No.4, (Auguest 1992), pp. 929-936, ISSN 0021-9525 
Selsted ME, Ouellette AJ. (1995). Defensins in granules of phagocytic and non-phagocytic cells. Trends in Cell Biology, Vol.5, No.3, (March 1995), pp. 114-119, ISSN 0962-8924

Selsted ME, Ouellette AJ. (2005). Mammalian defensins in the antimicrobial immune response. Nature Immunology, Vol.6, No.6, (June 2005), pp. 551-557, ISSN 1529-2908

Sherman MP, Bennett SH, Hwang FF, Sherman J, Bevins CL. (2005). Paneth Cells and Antibacterial Host Defense in Neonatal Small Intestine. Infection and Immunity, Vol.73, No.9, (September 2005), pp. 6143-6146, ISSN 0019-9567

Shi J. (2007). Defensins and Paneth cells in inflammatory bowel disease. Infammatory Bowel Diseases, Vol.13, No.10, (October 2007), pp. 1284-1292, ISSN 1078-0998

Shirafuji Y, Tanabe H, Satchell DP, Henschen-Edman A, Wilson CL, Ouellette AJ. (2003). Structural determinants of procryptdin recognition and cleavage by matrix metalloproteinase-7. Journal of Biological Chemistry, Vol.278, No.10, (March 2003), pp. 7910-7919, ISSN 0021-9258

Skalicky JJ, Selsted ME, Pardi A. (1994). Structure and dynamics of the neutrophil defensins NP-2, NP-5, and HNP-1: NMR studies of amide hydrogen exchange kinetics. Proteins, Vol.20, No.1, (September 1994), pp. 52-67, ISSN 0887-3585

Solomon S, Hu J, Zhu Q, Belcourt D, Bennett HP, Bateman A, Antakly T. (1991). Corticostatic peptides. Journal of Steroid Biochemistry and Molecular Biology, Vol.40, No.1-3, (no date), pp. 391-398, ISSN 0960-0760

Sparkes RS, Kronenberg M, Heinzmann C, Daher KA, Klisak I, Ganz T, Mohandas T. (1989). Assignment of defensin gene(s) to human chromosome 8p23. Genomics, Vol.5, No.2, (Auguest 1989), pp. 240-244, ISSN 0888-7543

Strober W, Fuss I, Mannon P. (2007). The fundamental basis of inflammatory bowel disease. Journal of Clinical Investigation, Vol.117, No.3, (March 2007), pp. 514-521, ISSN 00219738

Tanabe H, Qu X, Weeks CS, Cummings JE, Kolusheva S, Walsh KB, Jelinek R, Vanderlick TK, Selsted ME, Ouellette AJ. (2004a). Structure-activity determinants in paneth cell alpha-defensins: loss-of-function in mouse cryptdin-4 by charge-reversal at arginine residue positions. Journal of Biological Chemistry, Vol.279, No.12, (March 2004), pp. 11976-11983, ISSN 0021-9258

Tanabe H, Yuan J, Zaragoza MM, Dandekar S, Henschen-Edman A, Selsted ME, Ouellette AJ. (2004b). Paneth cell alpha-defensins from rhesus macaque small intestine. Infection and Immunity, Vol.72, No.3, (March 2004), pp. 1470-1478, ISSN 0019-9567

Tang YQ, Yuan J, Osapay G, Osapay K, Tran D, Miller CJ, Ouellette AJ, Selsted ME. (1999). A cyclic antimicrobial peptide produced in primate leukocytes by the ligation of two truncated alpha-defensins. Science, Vol.286, No.5439, (October 1999), pp. 498502, ISSN 0036-8075

Tani K, Murphy WJ, Chertov O, Salcedo R, Koh CY, Utsunomiya I, Funakoshi S, Asai O, Herrmann SH, Wang JM, Kwak LW, Oppenheim JJ. (2000). Defensins act as potent adjuvants that promote cellular and humoral immune responses in mice to a lymphoma idiotype and carrier antigens. International Immunology, Vol.12, No.5, (May 2000), pp. 691-700, ISSN 0953-8178

Territo MC, Ganz T, Selsted ME, Lehrer R. (1989). Monocyte-chemotactic activity of defensins from human neutrophils. Journal of Clinical Investigation, Vol.84, No.6, (December 1989), pp. 2017-2020, ISSN 0021-9738 
Tominaga T, Fukata J, Naito Y, Nakai Y, Funakoshi S, Fujii N, Imura H. (1990). Effects of corticostatin-I on rat adrenal cells in vitro. Journal of Endocrinology, Vol.125, No.2, (May 1990), pp. 287-292, ISSN 0022-0795

Trabi M, Schirra HJ, Craik DJ. (2001). Three-dimensional structure of RTD-1, a cyclic antimicrobial defensin from Rhesus macaque leukocytes. Biochemistry, Vol.40, No.14, (April 2001), pp. 4211-4221, ISSN 0006-2960

Tran D, Tran P, Roberts K, Osapay G, Schaal J, Ouellette A, Selsted ME. (2008). Microbicidal properties and cytocidal selectivity of rhesus macaque theta defensins. Antimicrobial Agents Chemotherapy, Vol.52, No.3, (March 2008), pp. 944-953, ISSN 0066-4804

Tran D, Tran PA, Tang YQ, Yuan J, Cole T, Selsted ME. (2002). Homodimeric theta-defensins from rhesus macaque leukocytes: isolation, synthesis, antimicrobial activities, and bacterial binding properties of the cyclic peptides. Journal of Biological Chemistry, Vol.277, No.5, (Feburary 2002), pp. 3079-3084, ISSN 0021-9258

Valore EV, Ganz T. (1992). Posttranslational processing of defensins in immature human myeloid cells. Blood, Vol.79, No.6, (March 1992), pp. 1538-1544, ISSN 0006-4971

Valore EV, Martin E, Harwig SS, Ganz T. (1996). Intramolecular inhibition of human defensin HNP-1 by its propiece. Journal of Clinical Investigation, Vol.97, No.7, (April 1996), pp. 1624-1629, ISSN 0021-9738

Valore EV, Park CH, Quayle AJ, Wiles KR, McCray PB Jr, Ganz T. (1998). Human betadefensin-1: An antimicrobial peptide of urogenital tissues. Journal of Clinical Investigation, Vol.101, No.8, (April 1998), pp. 1633-1642, ISSN 0021-9738

Van Es JH, Jay P, Gregorieff A, van Gijn ME, Jonkheer S, Hatzis P, Thiele A, van den Born M, Begthel H, Brabletz T, Taketo MM, Clevers H. (2005). Wnt signaling induces maturation of Paneth cells in intestinal crypts. Nature Cell Biology, Vol.7, No.4, (April 2005), pp. 381-386, ISSN 1476-4679

Voss E, Wehkamp J, Wehkamp K, Stange EF, Schröder JM, Harder J. (2006). NOD2/CARD15 mediates induction of the antimicrobial peptide human betadefensin-2. Journal of Biological Chemistry, Vol.281, No.4, (January 2006), pp. 20052011, ISSN 0021-9258

Wang, W., S. M. Owen, D. L. Rudolph, A. M. Cole, T. Hong, A. J. Waring, R. B. Lal, and R. I. Lehrer. (2004). Activity of alpha- and theta-defensins against primary isolates of HIV-1. Journal of Immunology, Vol.173, No.1, (July 2004), pp. 515-520, ISSN 00221767

Wehkamp J, Chu H, Shen B, Feathers RW, Kays RJ, Lee SK, Bevins CL. (2006). Paneth cell antimicrobial peptides: Topographical distribution and quantification in human gastrointestinal tissues. FEBS Letters, Vol.580, No.22, (October 2006), pp. 5344-5350, ISSN 0014-5793

Wehkamp J, Fellermann K, Herrlinger KR, Baxmann S, Schmidt K, Schwind B, Duchrow M, Wohlschläger C, Feller AC, Stange EF. (2002). Human beta-defensin 2 but not betadefensin 1 is expressed preferentially in colonic mucosa of inflammatory bowel disease. European Journal of Gastroenterology \& Hepatology, Vol.14, No.7, (July 2002), pp. 745-752, ISSN 0954-691X

Wehkamp J, Harder J, Weichenthal M, Mueller O, Herrlinger KR, Fellermann K, Schroeder JM, Stange EF. (2003). Inducible and constitutive beta-defensins are differentially expressed in Crohn's disease and ulcerative colitis. Inflammatory Bowel Diseases, Vol.9, No.4, (July 2003), pp. 215-223, ISSN 1078-0998 
Wehkamp J, Harder J, Weichenthal M, Schwab M, Schäffeler E, Schlee M, Herrlinger KR, Stallmach A, Noack F, Fritz P, Schröder JM, Bevins CL, Fellermann K, Stange EF. (2004). NOD2 (CARD15) mutations in Crohn's disease are associated with diminished mucosal alpha-defensin expression. Gut, Vol.53, No.11, (November 2004), pp. 1658-1664, ISSN 00017-5749

Wehkamp J, Salzman NH, Porter E, Nuding S, Weichenthal M, Petras RE, Shen B, Schaeffeler E, Schwab M, Linzmeier R, Feathers RW, Chu H, Lima H Jr, Fellermann K, Ganz T, Stange EF, Bevins CL. (2005). Reduced Paneth cell alpha-defensins in ileal Crohn's disease. Proceedings of the National Academy of Sciences USA, Vol.102, No.50, (December 2005), pp. 18129-18134, ISSN 1091-6490

Wilson CL, Ouellette AJ, Satchell DP, Ayabe T, López-Boado YS, Stratman JL, Hultgren SJ, Matrisian LM, Parks WC. (1999). Regulation of intestinal alpha-defensin activation by the metalloproteinase matrilysin in innate host defense. Science, Vol.286, No.5437, (October 1999), pp. 113-117, ISSN 0036-8075

Yamaguchi N, Isomoto H, Mukae H, Ishimoto H, Ohnita K, Shikuwa S, Mizuta Y, Nakazato M, Kohno S. (2009). Concentrations of alpha- and beta-defensins in plasma of patients with infammatory bowel disease. Infammation Research, Vol.58, No.4, (April 2009), pp. 192-197, ISSN 1023-3830

Yang D, Chen Q, Chertov O, Oppenheim JJ. (2000). Human neutrophil defensins selectively chemoattract naive $\mathrm{T}$ and immature dendritic cells. Journal of Leukocyte Biology, Vol.68, No.1, (July 2000), pp. 9-14, ISSN 0741-5400

Yang D, Chertov O, Bykovskaia SN, Chen Q, Buffo MJ, Shogan J, Anderson M, Schröder JM, Wang JM, Howard OM, Oppenheim JJ. (1999). Beta-defensins: linking innate and adaptive immunity through dendritic and T cell CCR6. Science, Vol.286, No.5439, (October 1999), pp. 525-528, ISSN 0036-8075

Yount NY, Wang MS, Yuan J, Banaiee N, Ouellette AJ, Selsted ME. (1995). Rat neutrophil defensins. Precursor structures and expression during neutrophilic myelopoiesis. Journal of Immunology, Vol.155, No.9, (November 1995), pp. 4476-4484, ISSN 00221767

Zasloff M. (2002). Antimicrobial peptides of multicellular organisms. (2002). Nature, Vol.415, No.6870, (January 2002), pp. 389-395, ISSN 0028-0836

Zhang XL, Selsted ME, Pardi A. (1992). NMR studies of defensin antimicrobial peptides. 1. Resonance assignment and secondary structure determination of rabbit NP-2 and human HNP-1. Biochemistry, Vol.31, No.46, (November 1992), pp. 11348-11356, ISSN 0006-2960

Zhu Q, Bateman A, Singh A, Solomon S. (1989). Isolation and biological activity of corticostatic peptides (anti-ACTH). Endocrinology Research, Vol.15, No.1-2, (no date), pp. 129-149, ISSN 0743-5800

Zhu Q, Singh A, Bateman A, Esch F, Solomon S. (1987). The corticostatic (anti-ACTH) and cytotoxic activity of peptides isolated from fetal, adult and tumor-bearing lung. Journal of Steroid Biochemistry, Vol.27, No.4-6, (no date), pp. 1017-1022, ISSN 09600760

Zimmermann GR, Legault P, Selsted ME, Pardi A. (1995). Solution structure of bovine neutrophil beta-defensin-12: the peptide fold of the beta-defensins is identical to that of the classical defensins. Biochemistry, Vol.34, No.41, (October 1995), pp. 1366313671, ISSN 0006-2960 


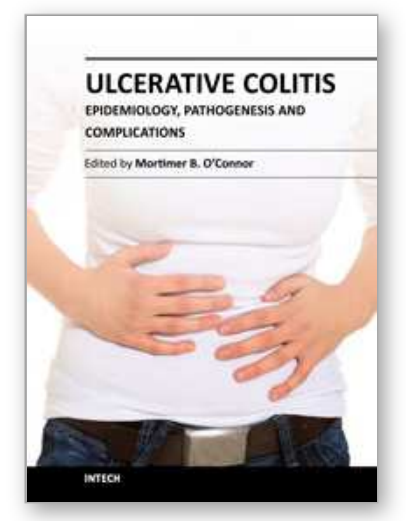

\author{
Ulcerative Colitis - Epidemiology, Pathogenesis and Complications \\ Edited by Dr Mortimer O'Connor
}

ISBN 978-953-307-880-9

Hard cover, 280 pages

Publisher InTech

Published online 14, December, 2011

Published in print edition December, 2011

This book is intended to act as an up-to-date reference point and knowledge developer for all readers interested in the area of gastroenterology and in particular, Ulcerative Colitis. All authors of the chapters are experts in their fields of publication, and deserve individual credit and praise for their contributions to the world of Ulcerative Colitis. We hope that you will find this publication informative, stimulating, and a reference point for the area of Ulcerative colitis as we move forward in our understanding of the field of medicine.

\title{
How to reference
}

In order to correctly reference this scholarly work, feel free to copy and paste the following:

Zhanju Liu and Yurong Yang (2011). Defensins in Ulcerative Colitis, Ulcerative Colitis - Epidemiology, Pathogenesis and Complications, Dr Mortimer O'Connor (Ed.), ISBN: 978-953-307-880-9, InTech, Available from: http://www.intechopen.com/books/ulcerative-colitis-epidemiology-pathogenesis-andcomplications/defensins-in-ulcerative-colitis

\section{INTECH}

open science | open minds

\author{
InTech Europe \\ University Campus STeP Ri \\ Slavka Krautzeka 83/A \\ 51000 Rijeka, Croatia \\ Phone: +385 (51) 770447 \\ Fax: +385 (51) 686166 \\ www.intechopen.com
}

\section{InTech China}

Unit 405, Office Block, Hotel Equatorial Shanghai

No.65, Yan An Road (West), Shanghai, 200040, China 中国上海市延安西路65号上海国际贵都大饭店办公楼 405 单元

Phone: +86-21-62489820

Fax: +86-21-62489821 
(C) 2011 The Author(s). Licensee IntechOpen. This is an open access article distributed under the terms of the Creative Commons Attribution 3.0 License, which permits unrestricted use, distribution, and reproduction in any medium, provided the original work is properly cited. 